\title{
Effects of Calcination Temperatures on The Catalytic Activities of Alumina Supported Cobalt and Chromium Catalysts
}

\author{
Mardwita Mardwita $^{1 *}$, Eka Sri Yusmartini ${ }^{1}$, Nidya Wisudawati ${ }^{2}$ \\ ${ }^{1}$ Chemical Engineering Department, Faculty of Engineering, Universitas Muhammadiyah Palembang, \\ Jl. Jend. Ahmad Yani 13 Ulu, Palembang 30263, Indonesia \\ ${ }^{2}$ Industrial Engineering Department, Faculty of Engineering, Universitas Muhammadiyah Palembang, \\ Jl. Jend. Ahmad Yani 13 Ulu, Palembang 30263, Indonesia
}

Received: 11 th April 2019; Revised: $9^{\text {th }}$ August 2019; Accepted: $18^{\text {th }}$ August 2019; Available online: 30th September 2019; Published regularly: December 2019

\begin{abstract}
Catalysts properties are important for catalytic reactions. The interaction between support and metal in a catalyst is resulted from catalyst preparation. In this study, gamma-alumina $\left(\mathrm{Al}_{2} \mathrm{O}_{3}\right)$ supported cobalt (Co) and chromium (Cr) catalysts were prepared by impregnation method and calcined at two different temperatures, they are $400{ }^{\circ} \mathrm{C}$ for 4 hours and $800{ }^{\circ} \mathrm{C}$ for 4 hours. The resulted catalysts contained 10 wt. $\%$ of metal and denoted as $\mathrm{Co} / \mathrm{Al}_{2} \mathrm{O}_{3}(400), \mathrm{Co} / \mathrm{Al}_{2} \mathrm{O}_{3} 3(800), \mathrm{Cr} / \mathrm{Al}_{2} \mathrm{O}_{3}(400)$, and $\mathrm{Cr} / \mathrm{Al}_{2} \mathrm{O}_{3}(800)$ catalysts. The surface and state of the catalysts were examined by using $\mathrm{x}$-ray diffraction (XRD), x-ray photoelectron spectrometer (XPS) and transmission electron microscopy (TEM). The XRD result reveals that strong interaction between $\mathrm{Co}$ and $\mathrm{Al}_{2} \mathrm{O}_{3}$ due to a formation of higher cobalt oxide. The XRD result further indicates aggregation and strong support metal interaction between Co and $\mathrm{Al}_{2} \mathrm{O}_{3}$ during calcination. On the other hand, TEM result showed that large Co particle was observed on $\mathrm{Al}_{2} \mathrm{O}_{3}$. The $\mathrm{Cr} / \mathrm{Al}_{2} \mathrm{O}_{3}$ catalysts were characterized by using XPS. The XPS results showed that $\mathrm{Cr} / \mathrm{Al}_{2} \mathrm{O}_{3}(800)$ catalyst was dominated by $\mathrm{Cr}^{6+}$ species at binding energy $579.04 \mathrm{eV}$, indicating high dispersion of $\mathrm{Cr}$ on $\mathrm{Al}_{2} \mathrm{O}_{3}$. Moreover, $\mathrm{Cr}$ metal particle was not observed on XRD and TEM image. All the characterization results provide information that the impregnated metal on $\mathrm{Al}_{2} \mathrm{O}_{3}$ showed different properties. Co metal particle tends to be more oxidized and formed large particle, however it was not observed on Cr metal particle. Copyright (C) 2019 BCREC Group. All rights reserved
\end{abstract}

Abstract

Keywords: Impregnation; Cobalt Catalyst; Chromium Catalyst; Methane Oxidation

How to Cite: Mardwita, M., Yusmartini, E.S., Wisudawati, N. (2019). Effects of Calcination Temperatures on The Catalytic Activities of Alumina Supported Cobalt and Chromium Catalysts. Bulletin of Chemical Reaction Engineering \& Catalysis, 14(3): 654-659 (doi:10.9767/bcrec.14.3.4673.654-659)

Permalink/DOI: https://doi.org/10.9767/bcrec.14.3.4673.654-659

\section{Introduction}

Heterogeneous catalyst plays an important role in catalytic reaction of chemical industries.

* Corresponding Author.

E-mail: wiwitdiita@gmail.com; mardwita@um-palembang.ac.id (M. Mardwita);

Telp.: +62-812-78201685, Fax: +62-711-519408
A catalyst contains two or more important compositions; they are a metal, a promoter, and a support. The metal is usually dispersed on a support to obtain a high surface area of an active metal. The catalytic property of the metal mainly depends on the interaction between metal and support. Therefore, metal-support interaction is important for the final catalysts properties. Some supports such as alumina $\left(\mathrm{Al}_{2} \mathrm{O}_{3}\right)$, 
silica $\left(\mathrm{SiO}_{2}\right)$ and titania $\left(\mathrm{TiO}_{2}\right)$ have been reported to exhibit strong metal-support interaction and low reducibility of metal [1-2]. As a consequence of these, the catalytic activity of the catalysts must be low. Catalysts treatment such as reduction and calcination temperatures somehow indirectly affected the catalysts properties through their metal-support interactions, crystallite sizes and oxidation states of the metals [3-5].

Among the various support, alumina is widely used and attracted much attention as catalyst support due to its high surface area, thermal resistance and stability at high temperature [6]. Alumina with transition metal such as cobalt $(\mathrm{Co})$ and chromium $(\mathrm{Cr})$ is widely applied to different industrially reactions, including methane oxidation and carbon monoxide hydrogenation [7-9]. In a high temperature catalytic reaction, a strong metal-support interaction may leads to the formation of a large metal particle. It is a known fact that the presence of a large metal particle on a support surface may serve as an inactive phase [10], therefore, it is necessary to make the metal particle as small as possible that leads to the high dispersion of active phase. Khangale et al. [11] studied the effect of activation with carbon monoxide (CO) for $\mathrm{Co} / \gamma-\mathrm{Al}_{2} \mathrm{O}_{3}$ catalyst, they found that $\mathrm{CO}$ can activates $\mathrm{Co} / \gamma-\mathrm{Al}_{2} \mathrm{O}_{3}$ catalyst at low temperature and improves catalyst reduction which is produced a higher number of active sites in the catalyst, hence increased the catalytic activity. Goodman [12] studied the catalytically active $\mathrm{Au}$ on $\mathrm{TiO}_{2}$, he found that strong metal-support interaction leads to the suppression of hydrogen $\left(\mathrm{H}_{2}\right)$ and carbon monoxide (CO) chemisorptions for various metal and for active $\mathrm{Au} / \mathrm{TiO}_{2}$ catalyst $\mathrm{CO}$ chemisorptions is enhanced due to electron transfer from $\mathrm{TiO}_{2}$ to $\mathrm{Au}$. Catalytic properties of alumina supported ruthenium $(\mathrm{Ru})$, platinum $(\mathrm{Pt})$, and cobalt (Co) nanoparticles was also investigated by Rekkab-Hammoumraoui and ChoukchouBraham [13], they concluded that the support, the noble and the non-noble metals can be active for oxidation of cyclohexane and they found that $\mathrm{Ru}$ and $\mathrm{Pt}$ are in metallic form whereas $\mathrm{Co}$ is in the oxides form.

Based on the view of the above reasons, the purpose of this study is to investigate the effect of calcination temperatures on the characterization and catalytic activity of alumina supported cobalt and chromium catalysts. The prepared catalysts were characterized by using $\mathrm{x}$ ray diffraction $(\mathrm{XRD}), \mathrm{x}$-ray photoelectron spectroscopy (XPS) and transmission electron microscopy (TEM) apparatus. The catalytic activi- ty of the catalysts was tested in methane oxidation reaction.

\section{Materials and Methods}

\subsection{Catalyst Preparation}

The catalysts preparation is described as follows. Four series of alumina supported cobalt and chromium catalysts were prepared by impregnation method. Gamma-alumina $\left(\gamma-\mathrm{Al}_{2} \mathrm{O}_{3}\right)$ was used as support. Two series of alumina supported cobalt $\left(\mathrm{Co} / \mathrm{Al}_{2} \mathrm{O}_{3}\right)$ catalysts were prepared using required amount of cobalt nitrate $\left(\mathrm{Co}\left(\mathrm{NO}_{3}\right)_{2} .6 \mathrm{H}_{2} \mathrm{O}\right.$, Merck) which was dissolved in aquadest and impregnated into $\mathrm{Al}_{2} \mathrm{O}_{3}$ powder. The solution was stirred and dried-up on a hot plate at $80{ }^{\circ} \mathrm{C}$ in order to remove the water. The resulted solid was kept in an oven at $80{ }^{\circ} \mathrm{C}$ for $12 \mathrm{~h}$. The loading of the Co was 10 wt.\%. To observe the effect of calcination temperatures, the solid was calcined in mixture of argon (Ar) and oxygen $\left(\mathrm{O}_{2}\right)$ at two different temperatures, $400{ }^{\circ} \mathrm{C}$ and $800{ }^{\circ} \mathrm{C}$, for $4 \mathrm{~h}$. The final catalysts were denoted as $\mathrm{Co} / \mathrm{Al}_{2} \mathrm{O}_{3}(400)$ and $\mathrm{Co} / \mathrm{Al}_{2} \mathrm{O}_{3}(800)$ catalysts. The same procedure of preparation and calcination as described above was also used to prepare alumina supported chromium $\left(\mathrm{Cr} / \mathrm{Al}_{2} \mathrm{O}_{3}\right)$ catalyst, where $\mathrm{Cr}\left(\mathrm{NO}_{3}\right)_{3} .9 \mathrm{H}_{2} \mathrm{O}$ (Merck) was used as the source of $\mathrm{Cr}$ metal. The final catalysts were denoted as $\mathrm{Cr} / \mathrm{Al}_{2} \mathrm{O}_{3}(400)$ and $\mathrm{Cr} / \mathrm{Al}_{2} \mathrm{O}_{3}(800)$ catalysts.

\subsection{Catalyst Characterization}

The XRD patterns have been recorded on Rigaku RINT-2500KS instrument by using $\mathrm{Cu}$ K $\alpha$ radiation source $(\lambda=1.54439 \AA)$ and scintillation counter detector at room temperature. The JCPDS data files were used to identify the XRD phases in the catalysts. The XPS measurements were made on Shimadzu PHI-5800 spectrometer using $\mathrm{Al} \mathrm{K} \alpha(\mathrm{h}=1486.0 \mathrm{eV})$ radiation as the excitation source. Before the measurements, the samples were kept in a vacuum overnight. The XPS analysis was done at room temperature and at pressure $1 \times 10^{-8} \mathrm{~Pa}$. The binding energies measured with accuracy of \pm $0.1 \mathrm{eV}$ and uses $\mathrm{C} 1 \mathrm{~s}$ at $284.5 \mathrm{eV}$ as standard. The TEM were conducted with a JEM-200CX $(200 \mathrm{kV})$ apparatus. The catalysts were kept in a vacuum overnight before the measurements.

\subsection{Catalyst Test}

The catalytic activities of $\mathrm{Co} / \mathrm{Al}_{2} \mathrm{O}_{3}(800)$ and $\mathrm{Cr} / \mathrm{Al}_{2} \mathrm{O}_{3}(800)$ catalysts were tested on methane oxidation reaction. The reactant gases consisted of methane $\left(\mathrm{CH}_{4}\right)$, oxygen $\left(\mathrm{O}_{2}\right)$ and 
argon (Ar) with total flow rate closed to $26 \mathrm{ml} /$ $\mathrm{min}$. The reaction temperature ranged from $300{ }^{\circ} \mathrm{C}$ to $480{ }^{\circ} \mathrm{C}$. A micro-reactor contained 0.25 grams catalyst was externally heated by a furnace. The products were detected using a thermal conductivity detector (TCD). Analysis of the products gases hardly detected any formation of carbon monoxide. The products of this reaction were carbon dioxide and water. The overall methane oxidation reaction is represented by Equation (1).

$$
\mathrm{CH}_{4}+2 \mathrm{O}_{2} \rightarrow \mathrm{CO}_{2}+2 \mathrm{H}_{2} \mathrm{O}
$$

The methane conversion was calculated from the peak areas obtained from the gas chromatograms. The methane conversion is defined by Equation (2).

$$
\mathrm{XCH}_{4}=\frac{\left(\text { amount of } \mathrm{CH}_{4} \text { in }- \text { amount of } \mathrm{CH}_{4} \text { out }\right)}{\left(\text { amount of } \mathrm{CH}_{4} \text { in }\right)}
$$

The concentration of each component is defined by Equation (3).

\section{Concentration $=$}

Area $\times$ Response factor $\times$ amount of component

\section{Results and Discussion}

The XRD measurements were recorded for $\mathrm{Co} / \mathrm{Al}_{2} \mathrm{O}_{3}$ catalysts subjected to calcination at $400{ }^{\circ} \mathrm{C}$ and $800{ }^{\circ} \mathrm{C}$. The $2 \theta$ data was collected by using a continuous scan mode ranged from $10^{\circ}$ to $70^{\circ}$. Figure 1 shows the XRD patterns of $\mathrm{Co} / \mathrm{Al}_{2} \mathrm{O}_{3}(400)$ and $\mathrm{Co} / \mathrm{Al}_{2} \mathrm{O}_{3}(800)$ catalysts. As can be seen in Figure 1, the XRD patterns con- firmed the existence of $\mathrm{Al}_{2} \mathrm{O}_{3}, \mathrm{CoAl}_{2} \mathrm{O}_{4}, \mathrm{CoO}$, and $\mathrm{Co}_{3} \mathrm{O}_{4}$ phase. The XRD pattern for $\mathrm{Co} /$ $\mathrm{Al}_{2} \mathrm{O}_{3}(800)$ catalyst is a little bit shifted to the right, this could be due to different phases on alumina and the transition of the phases as the calcination temperature increases. Based on the literature, on $\mathrm{Co} / \mathrm{Al}_{2} \mathrm{O}_{3}$ catalyst, the peaks of $\mathrm{Al}_{2} \mathrm{O}_{3}$ are at values of $46.1^{\circ}$ and $66.5^{\circ}$, while the peaks relate to Co metal should appeared at $2 \theta$ values of $43.8^{\circ}, 51.5^{\circ}$ and $75.6^{\circ}$, and the other cobalt oxides crystal planes are appeared at $2 \theta$ values of $36.5^{\circ}, 42.5^{\circ}$ and $60^{\circ}$ [14-15]. The chemical structure and structural phases for $\mathrm{Co}_{3} \mathrm{O}_{4}$ and $\mathrm{CoAl}_{2} \mathrm{O}_{4}$ are difficult to identify on both catalysts because $\mathrm{Co}_{3} \mathrm{O}_{4}$ and $\mathrm{CoAl}_{2} \mathrm{O}_{4}$ phase has almost identical diffraction peak position [16]. No peaks for Co metal were detected in XRD patterns, it might be due to the overlap with diffraction peaks of $\mathrm{Al}_{2} \mathrm{O}_{3}$ [15]. On the other hand, the diffraction peak at $61.8^{\circ}$ in both catalysts was due to $\mathrm{CoO}$ phase.

The main difference between the XRD patterns for both catalysts is the formation of $\mathrm{CoO}$ phase which is clearly detected in $\mathrm{Co} / \mathrm{Al}_{2} \mathrm{O}_{3}$ (800) catalyst at $2 \theta$ value of $42.7^{\circ}$. This result indicates the existence of $\mathrm{Co}_{3} \mathrm{O}_{4}$ phase in the surface of $\mathrm{Co} / \mathrm{Al}_{2} \mathrm{O}_{3}(400)$ catalyst, however the peak was not observed on the catalyst surface. Further calcination at high temperature increases the metal-support interaction and leads to the formation of $\mathrm{CoO}$ phase. It seems that $\mathrm{CoO}$ phase is formed during the calcination at high temperature $\left(>400{ }^{\circ} \mathrm{C}\right)$. In $\mathrm{Co} / \mathrm{Al}_{2} \mathrm{O}_{3}$ catalyst system, $\mathrm{Co}_{3} \mathrm{O}_{4}$ phase is a thermodynamically stable under the ambient

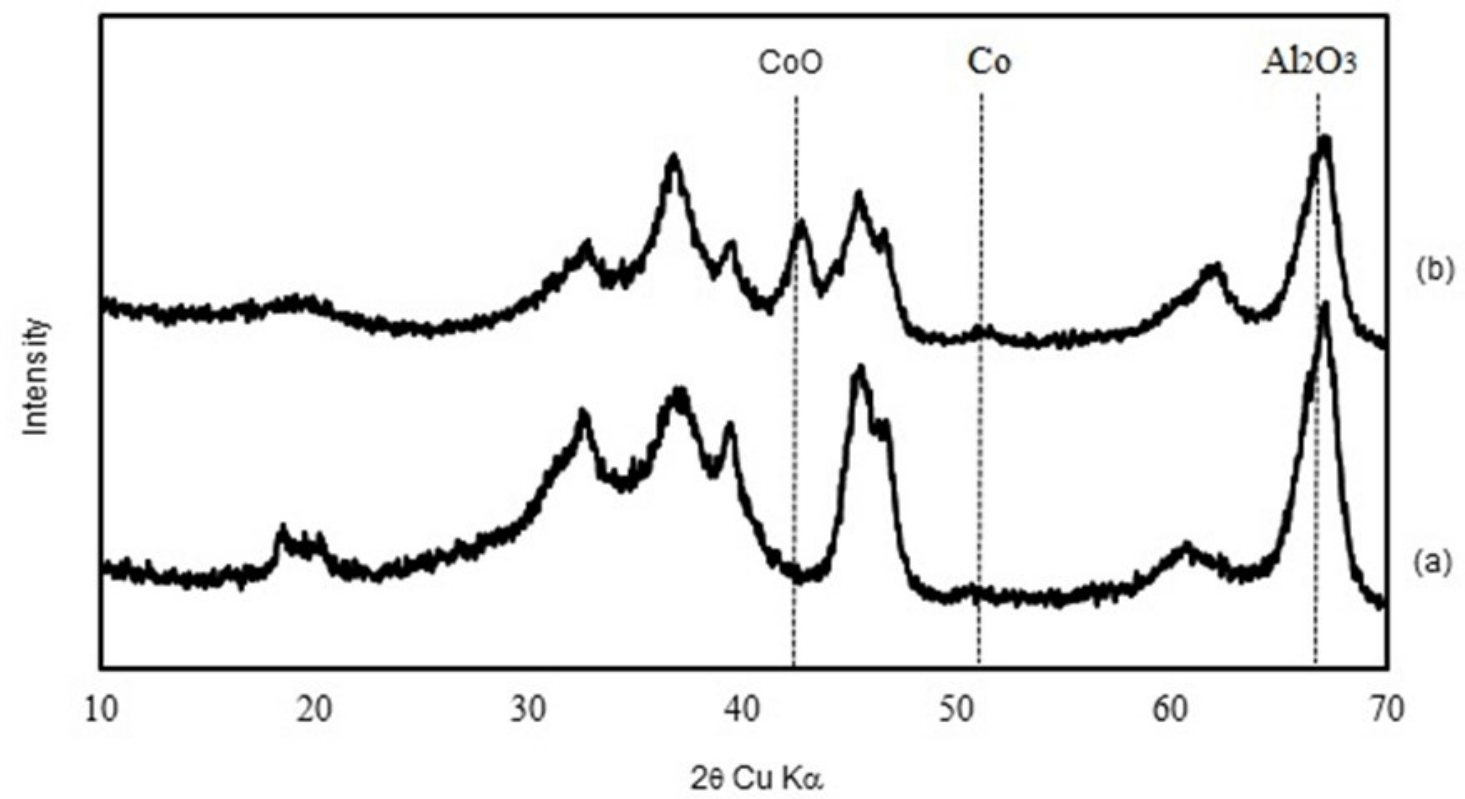

Figure 1. XRD patterns for (a) $\mathrm{Co} / \mathrm{Al}_{2} \mathrm{O}_{3}(400)$ and (b) $\mathrm{Co} / \mathrm{Al}_{2} \mathrm{O}_{3}(800)$ catalyst 
temperature and the formation of $\mathrm{CoO}$ phase can be expressed as follows [16].

$$
\mathrm{Co}_{3} \mathrm{O}_{4} \rightarrow 3 \mathrm{CoO}+1 / 2 \mathrm{O}_{2}
$$

Our results agreed well with Ji et al. [16], they found that when metal-support interaction is small, the catalyst is dominated by $\mathrm{Co}_{3} \mathrm{O}_{4}$ phase, on the other hand, $\mathrm{CoO}$ and $\mathrm{CoAl}_{2} \mathrm{O}_{4}$ phases are predominant on the catalyst surface when metal-support interaction increase.

The XPS measurements were only done for $\mathrm{Cr} / \mathrm{Al}_{2} \mathrm{O}_{3}(400)$ and $\mathrm{Cr} / \mathrm{Al}_{2} \mathrm{O}_{3}(800)$ catalysts, since a significant fraction of $\mathrm{Cr}$ is present as a small $\mathrm{Cr}_{2} \mathrm{O}_{3}$ particle that is detected by the XPS but is not by the XRD. Figure 2 displays XPS spectra for $\mathrm{Cr} / \mathrm{Al}_{2} \mathrm{O}_{3}$ catalysts. The XPS was conducted on curve-fitting area of $\mathrm{Cr}$ in range of $550-595 \mathrm{eV}$. The $\mathrm{Cr} 2 \mathrm{p} 3 / 2$ XPS peaks at binding energy values of $577.2 \mathrm{eV}$ and 579.8 $\mathrm{eV}$ are assigned to $\mathrm{Cr}^{3+}$ and $\mathrm{Cr}^{6+}$ species, respectively, as given by Rahman et al. [17]. The $\mathrm{Cr} / \mathrm{Al}_{2} \mathrm{O}_{3}(400)$ and $\mathrm{Cr} / \mathrm{Al}_{2} \mathrm{O}_{3}(800)$ catalysts were found to behave differently in calcination at $400{ }^{\circ} \mathrm{C}$ and $800{ }^{\circ} \mathrm{C}$ treatments. The XPS results showed that the $\mathrm{Cr} / \mathrm{Al}_{2} \mathrm{O}_{3}(400)$ catalyst has a predominantly $\mathrm{Cr}^{3+}$ species on the surface of support, whereas $\mathrm{Cr}^{6+}$ species was not observed a characterized by the $\mathrm{Cr} 2 \mathrm{p} 3 / 2$ signals at $577.0 \mathrm{eV}$ and $580.0 \mathrm{eV}$, respectively. It might be due to very small formation of $\mathrm{CrO}_{3}$ species. However, an interesting change was observed in the surface composition of the states of $\mathrm{Cr}$ after calcination at $800{ }^{\circ} \mathrm{C}$ for $4 \mathrm{~h}$. The differences in calcination temperatures between these catalysts seem affect to the general oxidation states behaviour. Two broad peaks were visible at binding energies $576.8 \mathrm{eV}$ and 579.04 $\mathrm{eV}$ which is assigned to the $\mathrm{Cr}^{3+}$ and $\mathrm{Cr}^{6+}$ species, respectively. The formation of $\mathrm{Cr}^{6+}$ species on $\mathrm{Cr} / \mathrm{Al}_{2} \mathrm{O}_{3}(800)$ catalyst could be due to a thermally activated process, since it was not found on $400{ }^{\circ} \mathrm{C}$ calcined catalyst. The hydroxyl groups and the structure of alumina might affect the formation of $\mathrm{Cr}^{6+}$ species. The calcination treatment at high temperature caused significant amount of $\mathrm{Cr}^{6+}$ species which suggest to better $\mathrm{Cr}$ dispersion [18]. However, these binding energies are shifted and lower compared to the binding energies obtained for
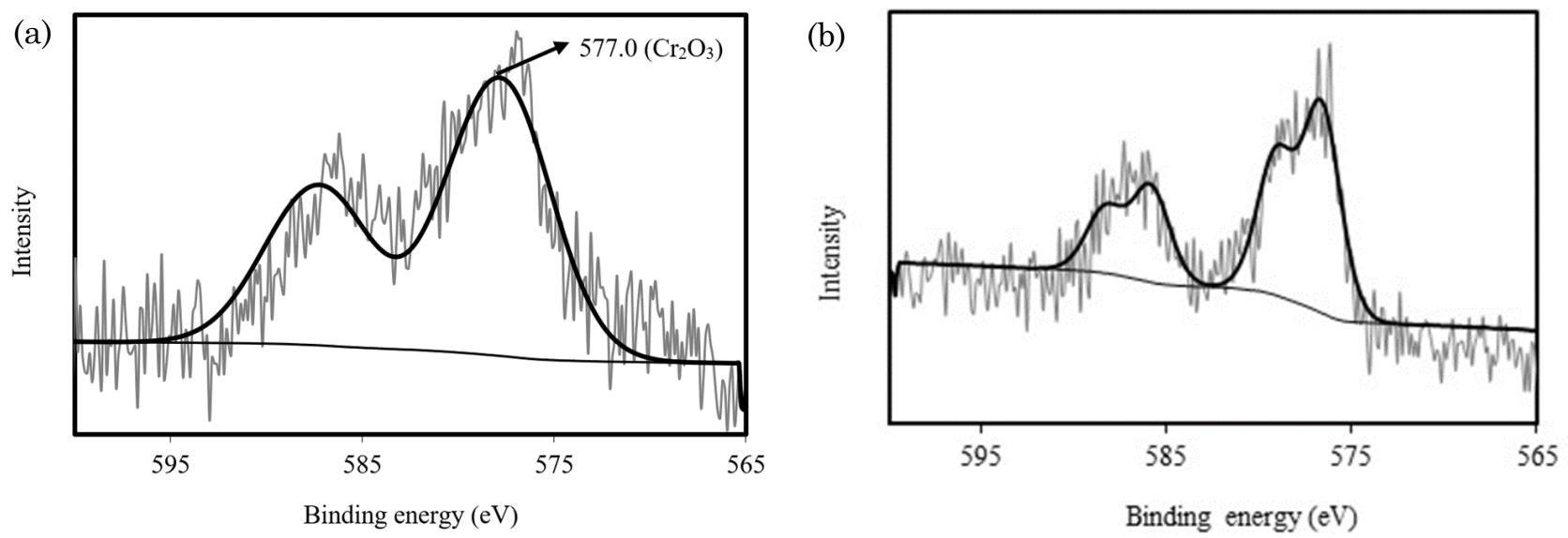

Figure 2. XPS spectra Cr 2p3/2 core level for a) $\mathrm{Cr} / \mathrm{Al}_{2} \mathrm{O}_{3}(400)$ and b) $\mathrm{Cr} / \mathrm{Al}_{2} \mathrm{O}_{3}(800)$ catalyst
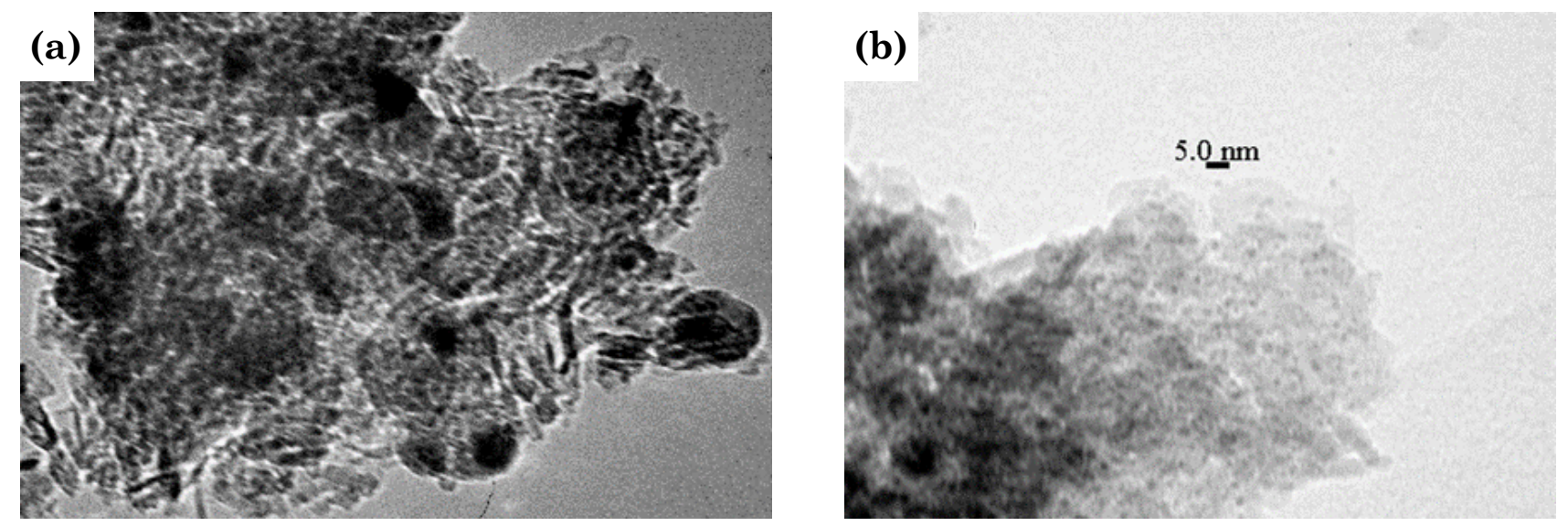

Figure 3. TEM images for (a) $\mathrm{Co} / \mathrm{Al}_{2} \mathrm{O}_{3}(800)$ and (b) $\mathrm{Cr} / \mathrm{Al}_{2} \mathrm{O}_{3}(800)$ catalyst 
$\mathrm{Cr} / \mathrm{Al}_{2} \mathrm{O}_{3}(400)$ catalyst as shown in Figure 2. The TEM images of $\mathrm{Co} / \mathrm{Al}_{2} \mathrm{O}_{3}(800)$ and $\mathrm{Cr} / \mathrm{Al}_{2} \mathrm{O}_{3}$ (800) catalysts are shown in Figure 3. TEM image of $\mathrm{Co} / \mathrm{Al}_{2} \mathrm{O}_{3}(800)$ catalyst showed large particles, it might due to agglomeration of Co particles during the calcination treatment, whereas TEM image of $\mathrm{Cr} / \mathrm{Al}_{2} \mathrm{O}_{3}(800)$ catalyst showed a very small black dot particles that might assigned to the highly dispersed $\mathrm{Cr}$ particles.

Figure 4 shows the comparison of $\mathrm{Co} / \mathrm{Al}_{2} \mathrm{O}_{3}(800)$ and $\mathrm{Cr} / \mathrm{Al}_{2} \mathrm{O}_{3}(800)$ catalysts over methane oxidation reaction. Both catalysts were active for methane oxidation and the catalysts started their catalytic activities at temperature higher than $250{ }^{\circ} \mathrm{C}$. The results showed that the catalytic activities for both catalysts increase with the increasing of temperatures. However, the catalytic activity of $\mathrm{Cr} / \mathrm{Al}_{2} \mathrm{O}_{3}(800)$ is relatively higher than $\mathrm{Co} / \mathrm{Al}_{2} \mathrm{O}_{3}(800)$ catalyst. It has been well-known that $\mathrm{Cr}^{6+}$ species is active for methane oxidation reaction as reported by Park and Ledford [19]. They studied $\mathrm{Cr} / \mathrm{Al}_{2} \mathrm{O}_{3}$ catalysts with different $\mathrm{Cr}$ loading and tested the catalytic activities over methane oxidation and found that the rich $\mathrm{Cr}^{6+}$ species catalyst gave the highest activity. Kuznetsova et al. [20] also studied the $\mathrm{Cr}$ catalysts for hydrocarbons destruction. They found that during the calcination treatments, the surface of alumina changes remarkably. The hydroxyl groups on the surface of alumina are responsible for the adsorptions of $\mathrm{Cr}$ from aqueous solution. High calcination temperatures may remove the hydroxyl groups on alumina hence increase the possibility for $\mathrm{Cr}$ adsorption onto alumina and increase the thermal stability of $\mathrm{Cr}^{6+}$ species. Therefore, at high calcination temperature, $\mathrm{Cr}^{6+}$ species is dominant species due to its thermal stability and active towards the reactions of hydrocarbons oxidation.

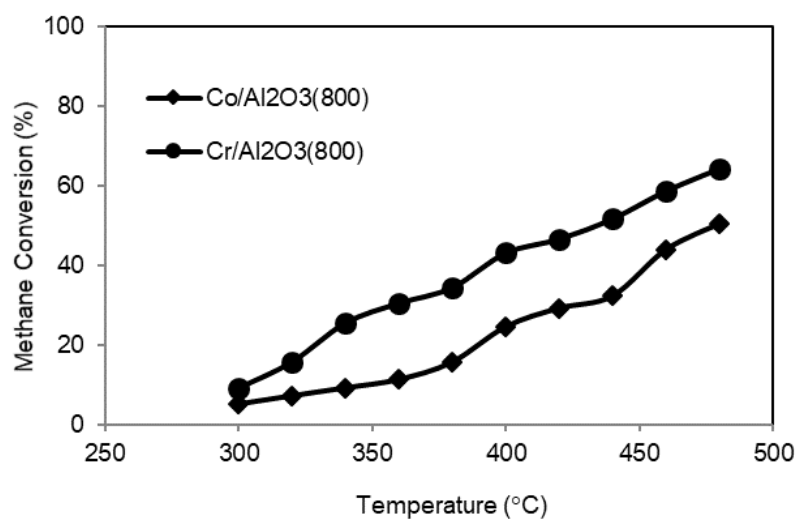

Figure 4. Methane conversion as a function of reaction temperature over $\mathrm{Co} / \mathrm{Al}_{2} \mathrm{O}_{3}(800)$ and $\mathrm{Cr} / \mathrm{Al}_{2} \mathrm{O}_{3}(800)$ catalyst

\section{Conclusions}

A series of alumina supported cobalt and chromium catalysts were prepared and calcined at different calcination temperatures $\left(400{ }^{\circ} \mathrm{C}\right.$ and $\left.800{ }^{\circ} \mathrm{C}\right)$. The XRD results showed that $\mathrm{Co} / \mathrm{Al}_{2} \mathrm{O}_{3}(800)$ catalyst was aggregated during calcination treatment and resulted $\mathrm{CoO}$ phase on the catalyst surface. The presence of $\mathrm{CoO}$ phase indicates higher metal-support interaction. On the other hand, XPS result for $\mathrm{Cr} / \mathrm{Al}_{2} \mathrm{O}_{3}(800)$ catalyst showed the $\mathrm{Cr}^{6+}$ species is dominant on the catalyst surface. High calcination temperature may remove the hydroxyl groups on alumina, Co particle may form an aggregation on alumina, and however Cr particle may adsorb and dispersed onto alumina. Both catalyst were active for methane oxidation and $\mathrm{Cr} / \mathrm{Al}_{2} \mathrm{O}_{3}(800)$ catalyst showed the higher activity than $\mathrm{Co} / \mathrm{Al}_{2} \mathrm{O}_{3}(800)$ catalyst due to the presence of $\mathrm{Cr}^{6+}$ species.

\section{Acknowledgment}

This research is funded by the grant from Directorate of Research and Community Service Directorate General of Research and Development (DRPM) The Ministry of Research Technology and Higher Education (RISTEKDIKTI) through the "Skim Hibah Desentralisasi: Penelitian Dasar Unggulan Perguruan Tinggi" Program, research contract number: SP DIPA-042.06.1.401516/2018.

\section{References}

[1] Ali, S., Mohd Zabidi, N.A., Al-Marri, M.J., Khader, M.M. (2016). Effect of the Support on Physicochemical Properties and Catalytic Performance of Cobalt Based Nanocatalysts in Fischer-Tropsch Reaction. Materials Today Communications, 10: 67-71.

[2] Ozawa, M., Yoshitoyo, N. (2016). Thermal Stability and Microstructure of Catalytic Alumina Composite Support with Lanthanum Species. Applied Surface Science, 380: 288293.

[3] Okumura, K., Niwa, M. (2002). MetalSupport Interaction which Controls the Oxidation State, Structure and Catalysis of Pd. Catalysis Surveys from Japan, 5: 121-126.

[4] Dey, S., Dhal, G.C., Mohan, D., Prasad, R. (2017). Effect of Preparation Conditions on the Catalytic Activity of $\mathrm{CuMnOx}$ Catalysts for CO Oxidation. Bulletin of Chemical Reaction Engineering \& Catalysis, 12(3): 431-451.

[5] Singha, R.K., Shukla, A., Yadav, A., Konathala, L.N.S., Bal, R. (2017). Effect of MetalSupport Interaction on Activity and Stability of $\mathrm{Ni}-\mathrm{CeO}_{2}$ Catalyst for Partial Oxidation of 
Methane. Applied Catalysis B: Environmental, 202: 473-488.

[6] Valdes-Martinez, O.U., Suarez-Toriello, V.A., De Los Reyes, J.A., Pawelec, B., Fierro, L.G. (2017). Support Effect and Metals Interactions for $\mathrm{NiRu} / \mathrm{Al}_{2} \mathrm{O}_{3}, \mathrm{TiO}_{2}$ and $\mathrm{ZrO}_{2}$ Catalysts in the Hydrodeoxygenation of Phenol. Catalysis Today, 296: 219-227.

[7] Mardwita, M., Matsune, H., Takenaka, S., Kishida, M. (2012). Chromium Addition to Alumina-Supported Platinum Catalysts and Effect on Catalytic in Methane Combustion. Journal of Chemical Engineering of Japan, 45: 493- 497.

[8] Mardwita, M., Bustan, M.D. (2017). Ammonium Hydroxide Addition and Its Influence on the Catalytic Activities of Pt-Based Catalysts for Methane Oxidation. MATEC Web of Conferences, 101: 1-6.

[9] Tijani, M.M., Aqsha, A., Mahinpey, N. (2017). Synthesis and Study of Metal-Based Oxygen Carriers $(\mathrm{Cu}, \mathrm{Co}, \mathrm{Fe}, \mathrm{Ni})$ and Their Interaction with Supported Metal Oxides $\left(\mathrm{Al}_{2} \mathrm{O}_{3}\right.$, $\mathrm{CeO}_{2}, \mathrm{TiO}_{2}, \mathrm{ZrO}_{2}$ ) in A Chemical Looping Combustion System. Energy, 138: 873-882.

[10] Murata, K., Mahara, Y., Ohyama, J., Yamamoto, Y., Arai, S., Satsuma, A. (2017). MetalSupport Interaction Concerning Particle Size Effect of $\mathrm{Pd} / \mathrm{Al}_{2} \mathrm{O}_{3}$ on Methane Combustion. Angewandte Chemie International Edition, 50: 15993-15997.

[11] Khangale, P.R., Meijboom, R., Jalama, K. (2019). Fischer-Tropsch Synthesis over Unpro-moted $\mathrm{Co} / \mathrm{y}-\mathrm{Al}_{2} \mathrm{O}_{3}$ Catalyst: Effect of Activation with $\mathrm{CO}$ Compared to $\mathrm{H}_{2}$ on Catalyst Performance. Bulletin of Chemical Reaction Engineering \& Catalysis, 14(1): 35-41.

[12] Goodman, D.W. (2005). Catalytically Active $\mathrm{Au}$ on Titania: Yet Another Example of A Strong Metal Support Interaction (SMSI)?. Catalysis Letter, 99: 1-4.
[13] Rekkab-Hammoumraoui, I., ChoukchouBraham, A. (2018). Catalytic Properties of Alumina-Supported Ruthenium, Platinum, and Cobalt Nanoparticles towards the Oxidation of Cyclohexane to Cyclohexanol and $\mathrm{Cy}$ clohexanone. Bulletin of Chemical Reaction Engineering \& Catalysis, 13(1): 24-36.

[14] Tavasoli, A., Abbaslou, R.M.M., Dalai, A.K. (2008). Deactivation Behavior of Ruthenium Promoted $\mathrm{Co} / \gamma \mathrm{Al}_{2} \mathrm{O}_{3}$ Catalysts in FischerTropsch Synthesis. Applied Catalysis A: General, 346: 58-64.

[15] Jongsomjit, B., Panranot, J., Goodwin, Jr.J. (2001). Co-Supported Compound Formation in Alumina-Supported Cobalt Catalysts. Journal of Catalysis, 204: 98-109.

[16] Ji, L., Lin, J., Zeng, H.C. (2000). MetalSupport Interactions in $\mathrm{Co} / \mathrm{Al}_{2} \mathrm{O}_{3}$ Catalysts: A Comparative Study on Reactivity of Support. The Journal of Physical Chemistry B, 104(8): 1783-1789.

[17] Rahman, A., Mohammed, M.H., Ahmed, M., Aitani, A.M. (1995). Characterization of Chromia.Alumina Catalysts by X-Ray Photoelectron Spectroscopy, Proton Induced X-Ray Emission and Thermogravimetric Analysis. Applied Catalysis A: General, 121: 203-216.

[18] Sainio, J., Aronniemi, M., Pakarinen, O., Kauraala, K., Airaksinen, S., Krause, O., Lahtinen, J. (2005). An Xps Study of CrOx on A Thin Alumina Film and in Alumina Supported Catalysts. Applied Surface Science, 252: 1076-1083.

[19] Park, W.P., Ledford, J.S. (1997). Characterization and $\mathrm{CH}_{4}$ Oxidation Activity of $\mathrm{Cr} / \mathrm{Al}_{2} \mathrm{O}_{3}$ Catalysts. Langmuir, 13: 2726-2730.

[20] Kuznetsova, L.L., Paukshtis, E.A., Shkurina, G.P., Shkrabina, R.A., Koryabkina, N.A., Arendarskii, D.A., Barannik, G.B., Ismagilov, Z.R. (1997). Chromium Catalysts for Hydrocarbons Destruction. Catalysis Today, 17: 209-216. 